\title{
SCENIC, SCIENTIFIC, AND HISTORIC IOWA AREAS ${ }^{1}$
}

\author{
By Edgar R. Hartan
}

In Iowa it is but a short spin from prairie lands to fairy lands. Even with moderate roads one can ride from Des Moines in an automobile through certain settlements which resemble parts of the heart of Europe, and others of aboriginal Iowa nature. You can see a natural bridge rivaling that of Virginia; caves of equal scientific interest with that of Kentucky; hills, valleys, plants, and fossils the glaciers left untouched; grottoes in which ice forms while the sun wilts the corn; lakes rimmed with boulders man cannot move.

One can see in Iowa lakes like those of Switzerland-only on levels where men till the soil and live. Stretches of the stone which is the foundation bedrock of the world rise in a forty-acre plot above our soil. Great hills on our Missouri River coast rise toward the clouds without a pebble in their structure. They were blown in drifts like snow from Nebraska plains before man was born. Thereon grow plants unknown except upon the arid western plains. Upon one of these hills you may stand where Lincoln stood, and with his long arm pointed to where the first iron horse should soon outrun the buffalo across lis native pastures toward the West.

You can retrace the Mormon trail-the course hundreds and thousands took across Iowa with ox teams and covered wagons - and in fancy you meet them rushing to the Golden West. In memory some of us yet living join the eastward-going throng returning from grasshopper-scourged claims of Kansas and $\mathrm{Ne}$ braska. On this old road you pass the sites of mills, bridges, ferries, camp sites, and graveyards placed by these first rovers overland. You cross the path of old John Brown, and the trail of Jesse James and see the bank he robbed.

Within the Black Hawk Purchase settlements first were made in Iowa. You see the fields first plowed to show to the Indians the white man's way of raising the corn and beans which the red

1 An address delivered before the Des Moines Rotarians at Hotel Fort Des Moines July 24, 1910. 
man had cultivated here before he had a paleface friend. There are the cornfields of Keokuk, Wapello, Hardfish, Kish-ke-kosh and Poweshiek. You see the council grove where these red chiefs in council with Governor Chambers sold Iowa to our government. You stand at the grave of Wapello and the site of Black Hawk's burial, you tread the ancient camp sites and battle fields of Indian times, and see the lock walls built in days of navigation of the Des Moines River.

You go through the region of the lower Des Moines, more interesting in the story of our state than is the lower James in the story of our nation. You see the most stupendous structures for power and navigation on the Mississippi, pass the sites of a dozen seats of learning of territorial days, visit the earlier capitols of Iowa, and the graves of nearly all our earlier statesmen.

'Throughout this five days tour, actual in my experience, you are always within thirty minutes of the mounds and works of prehistoric men; within sight or sound of locomotives and travel all the way between walls of growing corn and pastures of prize live stock. Not a single acre is available for less than $\$ 50.00,80$ per cent would cost $\$ 200$, and much of it sells at $\$ 400$ to $\$ 500$ per acre. You will be always within one hour of some institution of our state, built and operated ideally to relieve distress of mind or body.

But you cannot go swimming, boating, fishing, camping, nor play ball unless in cities, without trespassing. You cannot see one of the marvels I have named except over private lands; you cncounter hundreds of signs, "No Trespassing"; you examine nothing without consent. Some places you are distressed by finding owners have destroyed walnut and hickory groves and ledges and caves of stone because careless visitors, perchance, have sometimes left gates open or broken fences. Nor do you reasonably complain against such vandalism. The owners of these trees and blooded stock, or the caves and growing crops, are justified in this destruction. They paid real money for the lands, they spend their money for construction and upkeep of fences, and they pay their taxes perpetually for the proper enjoyment and profit of private and protected ownership.

Only a few years ago when the country was open the public generally resorted freely to the open lands. In many places may 
still be seen the ancient, deep-worn pathways crossed by fences. These paths were made by game, trod by the Indian, followed by the pioneer, and are still used by boys and men. These fences are broken by human streams along these paths exactly as the floods break the wire strands which cross their ancient channels. Men will exercise their ancient right of recreation. They will and do tramp the open as they did when they were boys. There always will be men and boys and they are not outlaws.

Recognizing these conflicting truths respecting these inharmonious interests, the state set out to open, acquire, and preserve some of these areas. Due compensation shall be made to private owners. Appropriate provision will be made that the healthful may resort to the open air with safety, without contempt of fellow citizens, and with full self-respect. Areas unique for scenery will be acquired. Those embracing objects and materials useful or interesting in scientific study will be reserved. Grounds will be bought whereon occurred important scenes in early and recent social life; where prehistoric works exist; where lie the ashes of our great; where shafts that speak of all these facts should stand. Shore lines of lakes and rivers, reservoirs, and steeps and slopes deforested in early days will be secured. Some will be replanted in time with useful and attractive trecs. Small roadside areas on streams, in shade, will be provided where families touring may camp overnight and rise in the morning, without passing cars having filled with dust their bed and breakfast. All this, in time to come, is the state's objective.

The State Board of Conservation was created by the Thirtyseventh General Assembly to advise with the Executive Council upon the application toward these ends of half the gun-license income. It was endowed and otherwise empowered by the Thirtyeighth General Assembly to accelerate the plan and $\$ 100,000$ per year for this purpose was set aside and is being prudently laid out.

The members of the Board are Dr. L.' H. Pammel of Ames, chairman; Hon. Joseph Kelso, Bellevue; Hon. John F. Ford, Fort Dodge; and Curator E. R. Harlan of Des Moines, secretary. ${ }^{2}$

2The present members of the Board are L. H. Pammel, Ames, president; Mrs. C. H. McNider, Mason City; Wm. E. G. Saunders, Emmetsburg; Mrs. E. F Armstrong, Fort Dodge; and Clifford L. Niles, Anamosa. R. E. Johnson, Des Moines, is secretary and W. C. Merckens, Des Moines, assistant secretary. 
The Board believes the advantages are mutual between centers of population and the state at large and that there is, in justice, an implied ratio of cost based on resulting benefits of acquisition between these two. It expects, regardless of local or general interest, to preserve certain areas for scientific and historical reasons. It expects to examine and consider every area mentioned by responsible citizens of the state. It has been offered areas cost free and has accepted them. It has been guaranteed areas at from ten to thirty-five per cent under appraised commercial values and has entertained with favor and purchased some of these. It has made arrangements to pay appraised values where local citizens from private sources have paid a part thereon. It has leased lands threatened at once to be despoiled, so that they shall remain of interest and value until zeal and funds accumulate wherewith to purchase them. It has viewed with deep concern the ring around all our lakes of privately owned and often highly improved properties, across which rings the public cannot go to where lie the banks and bodies of water belonging to the common public. Chagrin is felt from objection of some such owners against opening grounds nearby where parking sites and camping places can be established, to be made free and open to the Iowa citizen who can be there but a day or night each year. It has encountered with disgust lands yesterday for sale at bargain prices, today quoted to the state at double figures. It las advised that these will be at present passed to await completion of transactions which have in them full favor of localities affected. Especially are those localities favored that share with the state the original cost and offer further favors for the futurc. 'The Board gives notice that when the time comes for it to lay out full cash only for sucl arcas, it will call for condemnation through the law devised for acquiring the Capitol Grounds, viz: By appraisement by jurymen appointed by our chief justice and brought from other counties than those wherein lie the lands desired.

Already the state has acquired some 1200 acres in Delaware County, at present known as "The Back Bone Park." 'This is the area the pioneers denominated "The Devil's Back Bone" which lies about a great bend on the Maquoketa River. There the glaciers split when they leveled our prairies, left lofty, an- 
cient castellated rocks, covered with hoary moss and noble pine. Mammoth springs issue into the crystal stream which rushes on, the power of an old-time mill within the reservation.

At Farmington the citizens of Van Buren and Lee counties purchased and presented, cost free, 100 acres of virgin forest bearing every species of Iowa oak, some of gigantic size. A natural lake of 40 acres filled with gorgeous water lilies centers the tract.

At Keosauqua some 654 acres" of wild timber country bordering the Des Moines River, broken and brushy in places, level and cultivated in others, still has among its native denizens flocks of the old drumming pheasants or roughed grouse. Scores of coveys of the old bobwhite thrive there. There are dens of fur-bearing animals and nests of all the native birds. The whole is encircled by a good highway outside of which is a zone of private lands a mile in width whereon state rules for protecting animal and plant life are voluntarily respected and enforced as if state-owned. The lands in parcels sold usually at $\$ 45, \$ 55$, and $\$ 65$ per acre. It was optioned for our Board by a volunteer group of Keosauqua citizens and sold to the state at an average of $\$ 40$ per acre. The unique "Keosauqua Scheme" of helping the state purchase the tract was resorted to. Each interested individual subscribed the cost of an acre of the ground until the citizens had contributed $\$ 6,400.00$.

Near Muscatine at the Wild Cat Den two nature-loving pioneer women, the Brandt sisters, owned an area of some 60 acres which they offered, cost free, to the Board. Inspection of their tract proved it to be merely the heart of a region of immense interest. Accepting the gift, the Board proceeded' toward acquiring the rest of 300 acres at a cost to be shared between the state and citizens of the immediate region. The enlarged tract comes down along a fishing stream, includes a mill, opens upon a main highway and borders the Mississippi River.

A hundred other areas of similar character are under consideration. They are certain to be acquired in view of the fixed de-

3The Lacey-Keosauqua State Park now embraces 1,400 acres. Since the delivery of this address the conservation work has so grown that there are now under charge and control of the State Board of Conservation, twenty-nine state parks. Some came by gift, some by purchase, and some in part by gift and in part by purchase. 'They range in size from 1,400 acres to 5 acres. Several are on the shores of lakes, others are along the bluffs bordering streams. 
mand and need by the ordinary individual, by the scientist, and because of the historical, memorial, and recreational demands of those who have some depth of human interest or love for nature's ways.

\section{RED ROCK IN 1847}

Red Rock, eight and onc-half miles northwest from Knoxville, is a small town upon the bank of the Des Moines. It is located upon a timbered bottom, and presents quite a romantic appearance. It contains about twenty houses, two stores, one grocery, one hotel, and several mechanical shops. At about three-fourths of a mile from the town is the celebrated Red Rock, or the point from which the old Indian boundary line commenced. It began at this rock, and ran due south to the Missouri River, ${ }^{1}$ and due north to the neutral grounds. All the country west of this line was occupied by the Indians until October 11, 1845, at which time they were required by the terms of the treaty to move west of the Missouri. I should be pleased to give the reader a faint idea of the scenery in the vicinity of Red Rock, were it in my power to do so; but for this undertaking $I$ would need the graphic pen of an Irving, or the vivid imagination of a Lippard. Here Nature is seen in every form; along the river bottom, both wind and water seem to have conspired to uproot and level down the sturdiest trees, and to have thrown them in wild confusion amongst the standing timber, conveying the idea of a Red River raft upon dry land; while in the distance, and upon the margin of the valley, stupendous rocks and overhanging cliffs, gaily festooned with running vines and creeping moss, and a thousand varicties of stinted shrubs and diminutive trees, form a bold outline to the valley below. As for the Rock itself, I could see nothing so very remarkable about it except its color, which is quite red and very soft, and its singular projection above and over part of the river; a very good port, thought $I$, for a flat boat in a heavy shower of rain.-Weelsly Miners' Express, Dubuque, Iowa, September 15, 18.47. (In the newspaper collection of the Historical, Memorial and Art Department of Iowa.)

\footnotetext{
1This should have read "tlle Missouri state line,"-Editor.
} 
Copyright of Annals of Iowa is the property of State of Iowa, by \& through the State Historical Society of Iowa and its content may not be copied or emailed to multiple sites or posted to a listserv without the copyright holder's express written permission. However, users may print, download, or email articles for individual use. 